\title{
A Primer on Conducting Oil and Gas Operations IN THE NORTHERN ROCKY MOUNTAIN STATES: A Strange New World?
}

\author{
JOHN R. LEE, ESQ.
}

This article surveys issues relevant to Canadian oil and gas developers working in the northern Rocky Mountain states in the United States. It begins by providing an historical overview of land ownership in those states and then reviews the methods used to search for title to lands and potential resources therein. The author goes on to address several discrete areas which affect oil and gas operations in the northern Rocky Mountain states with a particular emphasis on oil and gas conservation.

\begin{abstract}
L'auteur examine des questions relatives aux promoteurs canadiens de projets pétroliers et gaziers dans les États américains de la région nord des Rocheuses. Après un survol historique du régime foncier et des modalités de recherche des titres et des ressources potentielles, l'auteur aborde plusieurs facteurs déterminants pour la mise en ceuvre des ressources pétrolières et gazières dans la région; et s'attache plus particulièrement à la conservation du pétrole et du gaz.
\end{abstract}

\section{TABLE OF CONTENTS}

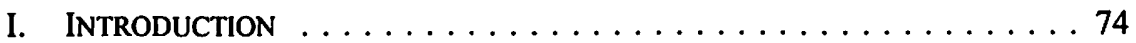

II. ACQUISITION AND DISPOSITION OF THE PUBLIC DOMAIN . . . . . 75

III. EXAMINATION OF TITLE $\ldots \ldots \ldots \ldots \ldots \ldots \ldots \ldots \ldots$

A. Federal Land Records $\ldots \ldots \ldots \ldots \ldots \ldots \ldots \ldots \ldots$

B. INDIAN LAND RECORDS $\ldots \ldots \ldots \ldots \ldots \ldots \ldots \ldots \ldots$

C. State LAND RECORdS $\ldots \ldots \ldots \ldots \ldots \ldots \ldots \ldots \ldots$

D. FEE LAND RECORDS $\ldots \ldots \ldots \ldots \ldots \ldots \ldots \ldots \ldots$

IV. SELECTEd OPERATING Considerations $\ldots \ldots \ldots \ldots \ldots \ldots \ldots 96$
A. SURFACE ACCESS AND

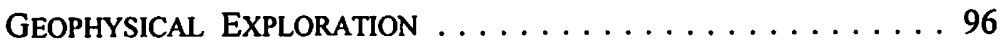


C. COMMENCING AND CONDUCTING OPERATIONS $\ldots \ldots \ldots \ldots 108$
D. IMMIGRATION MATTERS $\ldots \ldots \ldots \ldots \ldots \ldots \ldots \ldots$

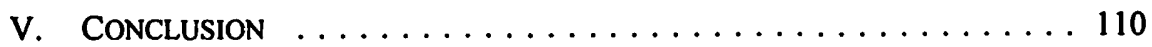

\section{INTRODUCTION}

The northern Rocky Mountain states of Montana, North Dakota, and Wyoming have historically been considered an excellent region within which to explore for and develop oil and gas resources. There are fifty-six counties in the State of Montana, with thirty-two of those counties having commercial oil or gas production. The principal producing regions are the Williston Basin (northeast Montana), Big Horn Basin (south-central Montana), Powder River region (southeast Montana), Sweetgrass Arch (northern Montana), and the central portion of Montana. North Dakota is comprised of

Partner, Crowley, Haughey, Hanson, Toole \& Dietrich P.L.L.P., Williston, North Dakota, U.S.A. The author also expresses his appreciation to Kemp J. Wilson, Michael E. Webster, and James P. Sites, partners in the Billings, Montana, U.S.A., offices of Crowley, Haughey, Hanson, Toole \& Dietrich P.L.L.P., for their contributions to this article. 
fifty-three counties, sixteen of which have commercial production (primarily oil with associated gas). These sixteen counties are located in the approximate western one-half of the state in the geologic province known as the Williston Basin. Wyoming contains twenty-three counties, the majority of which produce oil or gas in commercial quantities.

Canadian oil and gas developers making their initial foray into operations in the northern Rocky Mountain states will encounter what at first blush may appear to be a bewildering array of land ownership regimes and regulatory requirements. This article cannot, and does not, cover the waterfront of legal and operational issues which may arise in the course of conducting oil and gas operations below the 49th parallel. Rather, this article will provide an overview of the historical underpinnings of land ownership in those states, will discuss of why and how title is examined for purposes of determining that ownership, and, finally, will address certain selected areas impacting oil and gas operations in the northern Rocky Mountain states.

\section{ACquisition and Disposition of the Public domain}

One of the most fundamental, and yet most important, steps in the development of oil and gas resources in the United States is the determination of who holds title to the lands and resources sought to be developed. To effectively examine and analyze title to such lands and resources for purposes of making that determination, one must have some basic understanding of the evolution of land ownership in the northern Rocky Mountain states.

The United States acquired title to its vast western lands via a combination of purchase and conquest. The initial land acquisition to include portions of the northern Rocky Mountain states of Montana, North Dakota, and Wyoming was the Louisiana Purchase of 1803, which brought into American ownership 523 million acres at a price of three cents per acre. In 1818, Great Britain agreed to extend the Canadian border along the 49th parallel from Minnesota to the Rocky Mountains, thus giving the United States undisputed title to the balance of North Dakota. The Oregon Compromise of 1846 resolved the dispute between the British and the Americans over the northwest boundary of the United States, adding lands in northwestern Montana and west central Wyoming (along with Washington, Oregon and Idaho) to the rapidly growing nation. Finally, in 1850, five years after its annexation, Texas sold to the United States $78,842,880$ acres of its "western lands" for ten million dollars, adding to the territories that eventually became Wyoming, New Mexico, Oklahoma, Colorado, and Kansas.

The western lands which the United States acquired between 1803 and 1867 were also subject to the claims of their inhabitants, the American Indians. When the European settlers arrived, they entered and occupied these tribal homelands, relying upon the "discovery doctrine" to justify their intrusion.' Although the doctrine had the

The "discovery doctrine" was based upon a theory that the European settlers had "discovered" the lands on which they settled. See Oneida Indian Nation of New York v. New York, 69l F.2d 1070 (2d Cir. 1982) and authority cited therein. 
state's total area)." Finally, upon statehood, states also received an implicit grant of the beds underlying inland waters (to the high water mark) which were navigable on the date of statehood. This grant had its genesis in the "equal footing" doctrine which guaranteed that upon admission to the union, new states would possess governmental authority equal to all other states in the union. ${ }^{12}$ The ownership of beds underlying lakes and streams has spawned a myriad of litigation over the years, as navigable waters were not designated as such at the time of admission of a state into the union.

Congress also recognized that encouraging settlement of the western lands would require public aid for the construction of railroads and, commencing in 1850, embarked on a policy of subsidizing railroad construction by means of extensive land grants from the public domain. To further the construction of a transcontinental railroad, Congress devised a railroad land grant scheme, beginning with the Pacific Railroad Act of 1862. ${ }^{13}$ The Pacific Railroad Act, which was liberalized in $1864,{ }^{14}$ ultimately led to various railroad companies acquiring fee simple title to $14,739,697$ acres in Montana, 10,697,490 acres in North Dakota, and 5,749,051 acres in Wyoming. ${ }^{\text {is }}$ Congress later passed the General Right of Way Act of 1875 , which restricted the grant of lands to railroads to a mere easement without any rights to minerals underlying the rights of way. This reflected public disfavour with the railroad land grant system and a concomitant shift in Congressional policy. ${ }^{16}$

The northern Rocky Mountain states also have within their boundaries millions of acres of land held in trust by the United States for the use and benefit of Indians. Tribal Indian land is owned by the United States as trustee for the use and benefit of a tribe, group, or band of Indians. ${ }^{17}$ Allotted Indian lands are lands owned by the United States as trustee for the use and benefit of individual Indians. ${ }^{18}$ The vast majority of these lands are located within the exterior boundaries of Indian reservations. ${ }^{19}$ However, allotments were also made from public lands that remained subject to disposition to Indians not residing on a reservation or for whose tribe no reservation had been established, or in instances where the reservation was comprised of lands insufficient to allow allotments to be parceled out to each member of the tribe. ${ }^{20}$

Data from Public Land Statistics, 1966, 7-8; P. Gates, History of Public Land Law Development (Washington: U.S. Government Point Office, 1968) 38.

See Pollard v. Hagen, 44 U.S. 212 (1845).

12 Stat. 489 (1862).

13 Stat. 356 (1864).

Gates, supra note 11 at 385.

Great Northern Railway v. United States, 315 U.S. 262 (1942).

F. Cohen, Handbook of Federal Indian Law (Charlottesvill, Va.: Mitchie Bobbo-Merrill, 1982) at 606.

C. 119, 24 Stat. 388 (1887) (codified as amended at 25 U.S.C. $\$ 331-55$ (1988)).

For example, Montana is presently host to seven Indian reservations (the Blackfeet, Flathead, Fort Belknap, Fort Peck, Crow, Rocky Boys, and Northern Cheyenne) containing, in the aggregate, in excess of 5,000,000 acres. The Wind River Reservation in Wyoming is comprised of over 2,000,000 acres. The Fort Berthold, Turtle Mountain, Standing Rock, Sisseton-Wahpeton, and Fort Totten Reservations are located in North Dakota.

25 U.S.C. $\$ 334$ (1993). 
The BLM is the single most important federal agency for purposes of properly ascertaining title to oil and gas resources, primarily because of the vast acreage comprising public domain and acquired federal lands in the northern Rocky Mountain states administered by the BLM. It is also important because all private and state titles originated with or through the BLM (and its predecessor, the General Land Office). The function of the BLM records differs markedly from the purpose of county records (which will be discussed elsewhere in this article) in that BLM records are designed and maintained to carry out the management and administrative mandates of the BLM with respect to federal lands. The BLM state land office having jurisdiction over federal lands situated in the states of Montana and North Dakota is located in Billings, Montana, while the state land office having jurisdiction over federal lands in Wyoming is located in Cheyenne, Wyoming. ${ }^{24}$ Each state land office maintains serial register pages and case files relating to active actions affecting public lands under its jurisdiction along with a uniform records system consisting of master title plats reflecting land ownership and survey dates, use plats which depict current applications, leases, permits, and licenses, and an historical index which sets forth a chronological narrative of past and present actions affecting the public lands. ${ }^{25}$

A typical examination of the BLM state land office records for purposes of determining title to a federal oil and gas lease would proceed in the following fashion. Obviously, the scope of the examination will be contingent upon the purpose of the examination, the time parameters available for any given project, and cost versus risk considerations. For example, while a title opinion for drilling or division order purposes will require a detailed examination of all applicable records, if the records are being reviewed solely for determining the availability of federal lands for leasing within a prospect area, greater reliance on the plat system may be justified, albeit with the assumption of the attendant risks.

Assuming a detailed examination is required because a well is to be drilled on the federal oil and gas lease, the review would commence with the examination of the master title plat (often referred to as the "MT Plat"), the use plat, and the historical index. The MT Plat summarizes in graphic form the current ownership status of lands within a single township. The plat identifies those lands which continue to be public domain, lands which have been patented into private ownership, acquired lands, and lands which have been withdrawn or reserved by the United States for special purposes. As to those lands which have been patented into private ownership, the MT Plat will contain notations regarding minerals, including oil and gas, that may have been reserved to the federal government. Information which is difficult to display graphically is set forth on the right-hand side of the plat. Occasionally, if a portion of the township

25 Land information is now computerized in ALMRS (Automated Land and Mineral Record System), which transferred most serial register pages to a format which may be accessed by computer terminal in each state land office. The plat books, historical, and control documents indices are maintained on microfilm aperture cards. 
the examination of the assignments and other documentation located in the case file for the oil and gas lease.

Finally, each state land office maintains files, known as "case files," which document all actions affecting public lands. All current case files contain the original application for an interest in the public lands, whether for a patent, lease, license, or permit, and all subsequent documents relating to that particular transaction. With respect to a federal oil and gas lease, the case file provides the most important information regarding the lease and is therefore a critical component of any title examination to a federal lease. The case file, which may be comprised of multiple volumes depending upon the vintage of the lease and drilling activity thereon, contains pertinent documentation regarding issuance of the lease, a photocopy of the lease, and all assignments affecting ownership of the lease. The case file also contains other information concerning the lease such as correspondence between federal agencies regarding lease issuance, BLM notices relating to drilling and production activities, notices that the lease account has been transferred to the Minerals Management Service ("MMS") if an oil or gas discovery has been made on the lease, and other miscellaneous correspondence between the BLM and the lessees. The case file also contains rental receipts, accounting advices, and other documentation evidencing payments under the terms of applicable regulations. Where applicable, serial numbers of any communitization or unit agreement(s) affecting the lease are posted to the outside jacket of the case file. ${ }^{30}$

The BLM state land offices also contain numerous other records and files pertaining to the lands subject to their jurisdiction, including survey records, the mining claims index, acreage control cards, qualifications files, and sales files. The BLM district offices $^{31}$ maintain the case files for rights-of-way located in the relevant district along with records pertaining to KGS determinations. Depending on the scope and purpose of an examination, it may or may not be necessary to review these other records and files.

In addition to examining the BLM records, it is necessary to examine the records of the county within which the lands under examination are located. The county records provide constructive notice of their contents for purposes of application of the relevant state recording act to real property transfers, including assignments of interests in federal oil and gas leases. ${ }^{32}$ There is no federal statute providing that BLM records

Communitization agreements and unit agreements are serialized separately and contained within other case files which must be examined to determine their effect, if any, on the lease and lands under examination. It may also be necessary to examine other case files in areas of multiple mineral development (such as coal, mining, etc.) to determine whether the activities associated with such mineral may result in development conflicts. Williston Basin portion of North Dakota is handled out of the Dickinson District Office in Dickinson, North Dakota, while BLM district offices are located in Casper, Rawlins, Rock Springs, and Worland, Wyoming. See R. Hill, "Title Repositories, Recording, and Constructive Notice" (1983) 29 Rocky Mt. Min. L. Inst. 469. 
BIA, if the lands under examination were owned or administered at some point in time by any other federal agency, the examination of title to such lands should also include a review of the relevant records of that agency. Although an examination of title to Indian lands can commence at any of the records repositories to be discussed herein, the initial examination should begin at the BLM state land office since that location will typically disclose the earliest title data germane to the lands under examination and will provide some general information that may assist the title examiner when reviewing records at the other repositories.

The first item to be reviewed at the BLM state land office is the relevant MT Plat. Where the lands under examination lie within the exterior boundaries of an Indian reservation, that fact will be noted on the MT Plat. The plat will ordinarily reference the act, treaty, executive order, or other historical foundation for the establishment of the reservation. Special attention must be given to all dispositions of interests in the subject lands prior to the establishment of the reservation, including dispositions to mining claimants, railroads, homesteaders, state governments, or other federal agencies, since title may well be subject to the prior rights of those receiving such dispositions.

The title examiner must next examine the HI. Information reflected on the HI will include treaties, statutes, withdrawals, and other designations or governmental actions which may have application to the lands under examination. When dealing with allotted land, the allotment number for the allottee normally appears in conjunction with the trust patent entry shown on the $\mathrm{HI} .{ }^{39}$ The $\mathrm{HI}$ will also frequently reflect fee patents where such a patent issued to an individual Indian prior to 1957. Fee patents issued to individual Indians after 1957 will not typically be shown on the $\mathrm{HI}$ maintained at the BLM state land office but will instead be disclosed on the relevant MT Plat and HI system implemented by the BIA in that year. The HI will not disclose deeds to non-trust status ${ }^{40}$ nor certificates of competency ${ }^{41}$ since those documents originate within and are approved by the BIA, notwithstanding that the practical effect of these deeds and certificates is the same as issuance of a fee patent. Consequently, the HI maintained at the BLM state land office should not be relied upon to show all pertinent matters that might affect the Indian lands under examination.

Any special mineral plats on file at the BLM state land office which pertain to the lands under examination should also be reviewed to determine whether any possible conflicts with Indian mineral title may exist. Such determination is particularly critical when the lands of interest are ceded lands ${ }^{42}$ or where the lands being examined were

The HI normally discloses only those allotment selections for which issuance of a trust patent or restricted fee patent ultimately resulted.

41. Deeds to non-trust status terminate the trust status of the lands conveyed and are typically transfers to non-Indians or Indians to whom the United States owes no trust obligation. Sec 25 U.S.C. \& 405. described in the certificate. See e.g. 25 U.S.C. $\$ 372 ; 25$ C.F.R. $\$ 152.8$ and 152.9 (1991).

12 Ceded lands are those which have been conveyed by, or taken from, an Indian tribe with the intent to remove such lands from a reservation. In some instances, the tribe may retain title to mineral interests underlying the ceded lands even though the surface estate has been removed from the 
The BIA has established six primary land and titles records offices charged with the responsibility of recording, preserving, and maintaining records affecting titles to Indian lands. ${ }^{44}$ The land and titles records offices providing title services with respect to Indian lands in the northern Rocky Mountain states are located in Aberdeen, South Dakota, ${ }^{45}$ and Billings, Montana. ${ }^{46}$ The records systems maintained by these offices commence on the date of establishment or recognition of Indian title by the United States and extend through the date of the last activity or the date of the last posting. If Indian land is patented in fee simple, or if restrictions on alienation are removed, the applicable land titles and records office discontinues its recording of transactions affecting the land in question, since the land no longer continues to be under the jurisdiction of the BIA. Federal regulations otherwise mandate that any document affecting title or otherwise encumbering Indian land, including documents that must be recorded by virtue of BIA policy, be recorded with the appropriate land titles and records office. ${ }^{47}$

The BIA land titles and records office prepares and maintains a separate land index ${ }^{48}$ for each surveyed section of each township containing Indian lands which serves as a basic blueprint for all documents and transactions affecting Indian lands. The land index chronologically identifies all documents and transactions affecting title to the indexed lands, or any interest therein, from the inception of Indian ownership through the date of the most recent posting as evidenced on the index. With respect to tribal lands, the land index usually discloses the various treaties, statutes, or executive orders affecting the lands under examination. These items are not typically noted on the index for allotted lands unless the particular treaty, statute, or executive order specifically describes the allotted lands being examined.

The land index will disclose, for both tribal and allotted lands, any applicable deeds, distributions resulting from probates, orders eliminating restrictions, patents, rights-of-way, contracts for deed, mortgages, certificates of competency, and any other instruments affecting or encumbering Indian lands. Land index postings have also been expanded to include information on oil and gas leases as well as other types of leases. The land index does not reflect documents or transactions which have not been approved by the secretary of the interior or his designated representative.

If the lands under examination are allotted lands, the index will also disclose the particular allotment schedule containing the selection of the lands resulting in the allotment, along with the date the schedule was approved by the secretary of the interior or his authorized representative, followed in most instances by references to any patents that may have been issued for such lands. The land index must be scrutinized

25 C.F.R. $\$ 150.4$ (1991).

Aberdeen, South Dakota, provides title services for Indian lands under the jurisdiction of the Aberdeen and Minneapolis Area Offices, except for Indian lands located on the White Earth, Isabella, and Oneida Indian reservations, including Indian lands located in North Dakota.

Billings, Montana, provides title services for Indian lands under the jurisdiction of the Billings Area Office including Indian lands located in Montana and Wyoming.

25 C.F.R. $\S 150.3$ (1991).

The land index is also identified as "Form 5-125." 
number. ${ }^{52}$ Separate reception books, one for probates and one for all other documents, are maintained for each reservation under the jurisdiction of each land titles and records office. $^{53}$

In addition, all land titles and records offices maintain land status maps or land ownership plats, which graphically display land information and current ownership status for Indian lands within their jurisdiction. ${ }^{54}$ Many land titles and records offices also maintain mineral ownership plats which reflect mineral ownership status for Indian lands within their jurisdiction. When available, such maps and plats should be examined to confirm that mineral ownership status as reflected by those records is consistent with mineral ownership as determined from examination of the other records.

Although a detailed discussion of Indian succession and title examination of Indian probate files is beyond the scope of this article, it is important to note that Indian probate proceedings relating to trust real property interests located in the northern Rocky Mountain states are conducted by the Secretary of the Interior. ${ }^{55}$ The probating of estates of deceased Indians is conducted by administrative law judges within the Department of the Interior. ${ }^{56}$ The original records relating to Indian probate proceedings are retained by the BIA land titles and records office having jurisdiction over the particular land involved. ${ }^{57}$ In some instances, the probate may be complete but the file not yet transferred to the land titles and records office. When this situation arises, the title examiner must either examine the probate file in the office of the appropriate administrative law judge or request that the file be transmitted to the land titles and records office for examination. Review of Indian probate proceedings is a detailed process which requires the title examiner to be well-versed in all applicable laws, statutes, and regulations pertaining to both the procedural and substantive aspects of Indian succession. ${ }^{58}$

To properly examine title to Indian lands, it is also necessary to review the records and files of the BIA area offices having the lands under examination within their jurisdiction. With respect to Indian lands located within the northern Rocky Mountain states, the pertinent area offices are located in Billings, Montana, ${ }^{59}$ and Aberdeen, South Dakota. ${ }^{60}$ The area offices maintain the lease sale files for regularly advertised oil and gas lease sales which have occurred on reservations within their jurisdiction. Although certain sale information may not be available for public inspection because

25 C.F.R. \$ 150.6 (1991).

Ibid.

25 C.F.R. $\$ 150.9(1991)$

25 U.S.C. $\$ 372$ (intestate); 25 U.S.C. $\$ 373$ (testate). The Secretary of the Interior has, by statute, the exclusive jurisdiction to probate the estates of Indians with respect to trust lands or lands held subject to restraints on alienation. Ibid.

43 C.F.R. \$ 4.202 (1991).

25 C.F.R. $\$ 150.6$ (b) (1991).

For a detailed discussion of Indian succession and title examination of Indian probates, see supra note 38.

The Billings, Montana, Area Office covers Indian lands located within Montana and Wyoming. The Aberdeen, South Dakota, Area Office covers Indian lands located within North Dakota. 
current leases or permits by their contract or lease numbers, as well as their respective approval dates and dates of expiration in the absence of production.

The current leases and permits which are disclosed by the mineral lease and permit plats are normally filed at the agency and indexed according to the lease contract number or document number. The individual file for a current oil and gas lease will contain the original lease, including any acceptance sheets executed by multiple interest owners, as well as any original assignments, including assignments of overriding royalty or other interests in production which may have been filed with the agency. ${ }^{63}$ The files will often contain a fair amount of correspondence and documentation regarding bid acceptance, additional requirements to lease issuance, requests for additional time to comply with such requirements, and evidence of rental and bonus payments. If the lease covers tribal lands, the file will normally contain copies of tribal resolutions memorializing tribal consent to the lease and tribal authority for execution of the lease. If the oil and gas lease covers allotted lands, the lease file will likely contain information documenting the lessee's attempts to locate a missing heir who is an interest owner in the leased tract, particularly where the superintendent has executed the lease on behalf of the missing party. ${ }^{64}$ In short, virtually every document contained or referred to in a mineral lease or permit file potentially has an impact on the validity or effectiveness of the lease or permit. Consequently, it is imperative that the title examiner have access to the entire file without any segregation or editing by BIA personnel. Potential difficulties in gaining access to the entire lease file may usually be avoided by obtaining, prior to the examination, a letter from the lessee of the subject oil and gas lease, as disclosed by the records of the BIA, directed to the BIA requesting that the examiner be given unrestricted access to the entire lease file.

The BIA agency realty office is also the repository for the allotment folders or files for individual allottees of Indian lands located within the agency's jurisdiction. Allotment folders may contain a wide range of materials including allotment selection evidence, enrollment cards, patents, deeds, applications for fee patents, and a plethora of other documentation which may directly or indirectly bear on title to the allotted lands under examination. Occasionally, an allotment folder will contain opinions by the solicitor of the Department of the Interior or others, addressing particular title issues concerning the specific lands under examination. Because allotment folders often contain material that is of little value to the title examiner, such as private letters, financial records, or other matters which do not relate to land ownership, some BIA agency realty officers are reluctant to allow unbridled access to allotment folders and will allow a title examiner to review only that portion of the file which the officer deems to be "non-confidential" in nature. Where the file has been so segregated, a title examiner should either request permission to perform a cursory review of the redacted material to verify that such material does not affect title to the lands being examined,

6. Assignments of overriding royalty interests need not be filed with the BIA for approval. See 25 C.F.R. $\$ 212.22$ (d) (1991) (allotted leases).

(4) 25 C.F.R. $\$ 212.9$ (1991). The authority of the Superintendent to execute oil and gas leases for unlocatable lessors is not applicable where the unlocatable party is the original allottee. 
mineral lease cards, rental ledger sheets and accounting documentation, and lease files (both surface and mineral). By way of example, an examination of the records of the Montana Department of Natural Resources and Conservation, Trust Land Management Division for determining title to state lands would be conducted as follows. ${ }^{70}$

Having first confirmed the vesting of the lands under examination in the State of Montana by reviewing the relevant $\mathrm{HI}$ and CDI information at the BLM state land office, the current lease information is verified by examining the mineral lease cards. The rental ledger sheets and accounting documentation are then reviewed to confirm that all required payments, such as bonuses, delay rentals, and advance minimum rentals, have been timely paid in the proper amounts such that the lease account is in good standing. The lease case file, which contains documentation of all transactions affecting title to the oil and gas lease of interest, must then be examined. Like the records of the BLM, however, the records of the northern Rocky Mountain states' offices having jurisdiction over state lands do not provide constructive notice of their contents for purposes of being afforded the protection of the state recording statutes. This necessitates an examination of the records of the county within which the lands of interest are located.

\section{FEE LAND RECORDS}

For purposes of this discussion, the term "fee" or "fee lands" will be used in a general fashion to refer to lands owned by private parties as opposed to lands owned or administered by political subdivisions or agencies of the federal government, state lands, or Indian lands. In addition, although the nature of an examination of title to fee lands will vary depending upon the purpose of any specific project, this portion of the article will focus on the typical records examination conducted by a title attorney involved in preparing a title opinion prior to the drilling of an oil or gas well. ${ }^{71}$

In the northern Rocky Mountain states, the official records affecting title to fee lands, indeed, all real property located within a particular county, are maintained at the county courthouses in those states. The principal repository of title documentation is the county

The North Dakota State Land Department, located in Bismarck, has jurisdiction over the lands owned by the State and maintains all records concerning such lands. The Office of State Lands and Investments, located in Cheyenne, has jurisdiction over the lands owned by the State of Wyoming.

7 Title examinations can generally be broken down into four main categories. The first would be for purposes of acquiring leases (or other interests in minerals) in an area of interest. Typically, the reports prepared in the course of this acquisition phase would consist of "take-off reports" and "title memoranda" prepared by a petroleum landman. A second purpose for title examination is in connection with generating a "drilling title opinion," for the drilling phase of an exploration program, and is perhaps the most critical and comprehensive of all examinations. A third type of title examination is for preparing a "division order title opinion," which addresses transfers of interests in connection with the proper disbursement of production from a successful drilling venture. A final type of title examination would be a review of those records necessary to determine the interest ownership limited to a particular party for purposes of preparing a "financing opinion" for a lender securing a loan to that party by mortgaging mineral properties or production therefrom as collateral. 
reviewing an abstract of title, generally a "verbatim" abstract - little more than a compilation of photocopies of all records affecting the chain of title to the lands under examination prepared by a licensed abstractor. ${ }^{79}$ The primary advantage of examining title off abstracts is attorney efficiency. The attorney is not limited by the constraints of land office hours, competition for indices and records nor the need to travel with the attendant expense. On the other hand, abstracts are typically time consuming and expensive to prepare and may not contain all of the information necessary to pass on title. In the end, the type of examination conducted will be driven by the amount of land to be examined, the accessibility of the pertinent records, the complexity of the chain of title, and, perhaps most importantly, the time available to complete the examination and to prepare the title opinion.

Assuming the title attorney and the client have concluded that a stand-up examination is preferable, it will then be necessary to personally check the records and files maintained in the appropriate title repositories. The process involved in a typical title examination to fee lands is described below. The records repositories and examination methodology is very similar in Montana, North Dakota, and Wyoming, thus, for purposes of this article, a "garden variety" title examination in the context of drilling an oil and gas well on fee lands located in Montana will be discussed.

The examination of title to fee lands, like other lands, begins with a review of the records of the BLM state land office. As discussed previously, the MT Plats, OG Plats, $\mathrm{HI}$, and CDI, in addition to any other files indicated by an examination of the foregoing, must be reviewed to confirm that the federal government retained no residual interest in the mineral estate underlying the lands of interest. The title examiner must verify that the lands under examination are not affected by any executive orders, secretarial orders, or other public land laws which might prevent or hinder oil and gas development.

The title examiner next proceeds with the examination of the records in the appropriate county courthouse. In Montana, the county clerk and recorder may maintain unofficial tract indices, ${ }^{80}$ but the official indices for purposes of the recording statutes

Many operators have begun the practice of having an experienced landman "build" an abstract comprised of photocopies of all instruments affecting title rather than utilizing an abstracting service. This will generally result in a cost savings but also involves a somewhat greater degree of risk depending on the skill level and experience of the landman with the land records in the area of interest.

A tract index is designed to show a true chain of title to a particular tract of land by indexing against such tract (in chronological order) all instruments which have been recorded affecting title to such tract. In North Dakota, the county official charged with maintaining land records is called the Register of Deeds. Under North Dakota law, each Register of Deeds is required to keep a tract index, which is the official index for purposes of the recording statutes, and is also required to maintain separate grantor and grantee indices. See N.D. Cent. Code $\$ 11-18-07, \S 11-18-08$ (1997). The Wyoming county official in charge of the real property records, known as the County Clerk and Ex-Officio Recorder, is required by law to maintain official tract indices. See Wyo. Stat. $\S$ 18-3-402(a)(x), § 18-3-402(a)(xi) (1997). For a detailed discussed of tract indices, see P. Lear \& R. Hill, "Examination of Title to Fee Lands," Mineral Title Examination III, Paper No. 2 (Rocky Mtn. Min. L. Fdn., 1992) at 13-16. 
(7) note whether the conveyance is made subject to any encumbrances or prior reservations;

(8) determine whether the execution of the instrument appears regular on its face and, if the grantor is a party other than an individual, whether there is any obvious lack of authority or breach of fiduciary duty on the part of the party executing the instrument on behalf of the grantor;

(9) check the acknowledgment certificate to insure that it is in the required statutory form, properly completed, and signed; and

(10) note any other irregularities or unusual provisions in the instrument.

The examining attorney must also be aware of the nature of the instrument being examined, i.e., whether the recorded copy of the instrument is an exact photographic reproduction of the original instrument, a handwritten or typewritten copy, or a completed printed form which could contain errors made by the recording clerk. ${ }^{83}$

After the title examination has been completed and the mineral ownership determined, the attorney next prepares a list of parties for whom probates, mechanics' liens, tax liens, civil actions, judgments, and status of real property taxes must be checked.

Often in the course of a title examination, conveyance documents will indicate the death of one or more of the record title owners. In such cases, the records of the clerk of district court must be reviewed to determine if probate proceedings for the decedent were conducted in that county.$^{84}$ If so, the probate file must be examined to ensure the regularity of the proceedings and to verify that title to the lands under examination has devolved to the proper parties. Similarly, if the lands of interest have been the subject of civil proceedings, such as a quiet title action or mortgage foreclosure, the proper civil action files must be examined to confirm that the record title, as reflected by the records in the clerk and recorder's office, is in conformance with the decrees or judgments issued by the courts in such proceedings. Finally, the title examiner must review the judgments docket maintained in the clerk of district court's office to verify that no civil judgments have been filed against the owner(s) of any interest in the lands under examination. ${ }^{85}$

For example, patents from the United States to homesteaders were often "recorded" by filling in the blanks of pre-printed forms contained in "Patent Books" maintained by the clerk and recorder. This author has, on numerous occasions, examined such patents which did not contain a reservation of oil and gas (or other minerals) in favour of the federal government. However, the original patents at the BLM state land office did contain such a reservation.

Although property owned by a decedent devolves to his or her successors by operation of law, either original or ancillary probate proceedings conducted in the State of Montana are necessary to establish proper succession to the decedent's real property interests.

In Montana, the lien of a civil judgment, when docketed in the office of the Clerk of District Court, automatically attaches to all real property located in that county owned by the judgment debtor. See Mont. Code Ann. $\$ 25-9-301$ et seg. (1997). The lien remains in effect for six years 
trespass but may also be found where geophysical operations are conducted off the premises in question but are directed toward such premises. ${ }^{90}$ Consequently, in order to conduct geophysical exploration on or with respect to a particular tract, a permit to do so must be obtained, directly or indirectly, from the mineral owner of the tract. Where the mineral estate is unleased, and the mineral owner has not otherwise granted the right to explore to another party, the permit must be obtained directly from the mineral owner.

Assuming all or a portion of the mineral estate is subject to a valid and subsisting oil and gas lease, the lease carries with it, either expressly or impliedly, the right to explore for oil and gas, including the right to explore by geophysical means. ${ }^{91}$ This right is fully transferable. Thus, in the case of an oil and gas lease, a geophysical permit can be obtained from the lessee. The grant of the right to explore in an oil and gas lease can be either exclusive or non-exclusive. If the lessee's right to explore is expressly exclusive, the mineral owner cannot grant the right to a third party during the pendency of the lease. If the oil and gas lease is not expressly exclusive, the mineral owner retains the authority to grant the right to explore to others. ${ }^{92}$

Since the right to conduct mineral exploration is exclusive to the mineral estate, a severed surface estate owner has no power to grant a seismic permit to conduct geophysical exploration. ${ }^{93}$ Moreover, the surface estate is subservient to the dominant mineral estate in that the mineral owner or its lessee or permittee may enter and make reasonable use of the surface for mineral exploration, even though this right is not expressly created in the document whereby the mineral estate was severed from the surface estate. ${ }^{94}$ Therefore, a permit from the surface owner is not required in advance of conducting geophysical operations.

Even though the surface owner has no power to grant a permit to conduct geophysical exploration and the surface owner's consent is not required (unless otherwise required by law as discussed below), it is common practice to obtain seismic permits from the surface owner for purposes of settling surface damage issues. Although at common law a mineral owner, or its lessee or permittee, was not obligated to pay surface owners for damages resulting from the reasonable use of the surface, ${ }^{95}$ as a practical matter, it should be assumed that damages will be payable to the surface owner. North Dakota and Montana have both enacted statutes which, although not entirely clear on their faces, would likely be construed as requiring payment of surface damages for seismic operations. ${ }^{96}$ The author is unaware of any statutory requirements

See R. Rice, "Wrongful Geophysical Exploration" (1983) 44 Mon. L. Rev. 53.

Supra note 88, § 50.4(b).

The trend in most jurisdictions which have addressed this issue is that absent an express grant of the exclusive right to explore for minerals, the mineral owner retains a concurrent right to explore for minerals. Sec e.g. Mustang v. Texaco, 754 F.2d 892 at 895 (10th Cir. 1985); H. Williams \& C. Meyers, Oil and Gas Law $\$ 218.6$ note 7.

See Viking Oil, supra note 89.

See e.g. Western Energy v. Genie Land, 195 Mont. 202, 635 P.2d 1297, 1301 (1981).

See e.g. Norum v. Queen City Oil, 81 Mont. 527, 536, 264 P. 122 (1928).

N.D. Cent. Code $\S 38-11.1-01$ et seq. (1987); Mont. Code Ann. $\$ 82-10-501$ et seq. (1981). 
and to individual Indians, if allotted lands are involved. The regulations provide, however, that this dissemination of information may be modified by the terms of the permit, and, further, that the secretary shall treat such data as proprietary in nature and privileged for so long as is set forth in the permit, or, in the absence of any express time period, for six years.

For allotted lands, in some instances, a permit for exploration activities may be granted where fewer than all trust mineral owners consent to the operation. Consent to a permit may be granted where the mineral interest to be explored is vested in more than one party and consent has been acquired from owners of more than 50 percent of the minerals. A permit may also be granted when the whereabouts of one owner is unknown and all of the remaining owners consent to the permit, or when the secretary determines not only that there are so many owners of interests in a tract of land that it would be impractical to obtain their consent, but also that the desired activity can occur without substantial injury to the lands or any owner of an interest therein.

Finally, the allotted land regulations, but not the tribal land regulations, provide that no permit for geophysical exploration activities is required where the exploring party holds an oil and gas lease covering the lands to be explored and the lessor is also the surface owner. ${ }^{103}$ Where the allotted lands mineral owner is not the surface owner, however, the regulations require that the lessee intending to conduct seismic operations obtain "any additional necessary permits or rights of ingress or egress from the surface occupant." 104

\section{B. Oil and Gas Conservation}

Each of the northern Rocky Mountain states has enacted comprehensive oil and gas conservation legislation which largely utilizes well spacing and pooling as the primary conservation tools. ${ }^{105}$ The following discussion is focused primarily upon the conservation board and regulatory regime of Montana.

The Montana Board of Oil and Gas Conservation (the "Board") is a quasi-judicial board attached to the Department of Natural Resources and Conservation ("DNRC") for administrative support only. ${ }^{106}$ The Board's exercise of its quasi-judicial, licensing, and policy making functions is independent from, and beyond the approval or control of, the DNRC. ${ }^{107}$ The Board is comprised of seven members appointed by the Governor, who serve staggered terms. The members include industry representatives, mineral owner and surface owner representatives, and members at large. One Board member must be an attorney. ${ }^{108}$

25 C.F.R. $\$ 212.56$ (c) (1997).

Ibid.

K. Wilson, "Conservation Acts and Correlative Rights - Has the Pendulum Swung Too Far?" (1989) 35 Rocky Mtn. Min. L. Inst. 18-1. See e.g. Mont. Code Ann. tit. 82, c. I1, pt. 2 (1993); N.D. Cent. Code tit. 38, c. 8, pt. 8 (1987); Wyo. Stat. tit. 30, c. 5, pt. 1 (1977).

Mont. Code Ann. $\$ 2-15-3303$ (1997).

Mont. Code Ann. \$2-15-121 (1997).

Mont. Code Ann. \$2-15-124 (1997). 
for such temporary spacing units ${ }^{114}$ but generally includes within its orders a requirement that the applicant file an application for permanent spacing within a given number of days of successful well completion. This period is usually from ninety to 120 days. ${ }^{115}$ The Board may also increase or decrease the size of a temporary spacing unit or permit the drilling of increased density wells within a temporary spacing unit. ${ }^{116}$ The Board has also provided operators with flexibility in operations by granting requests for special spacing units for multiple formations, with the ability to drill either a vertical or a horizontal well with multiple laterals in the same formation, and by granting authority to commingle production from such multiple laterals in the same formation.

Montana's Oil and Gas Conservation Act requires, among other things, that notice of applications to drill wildcat (undelineated field) wells must be published, ${ }^{117}$ and, if a demand to be heard is received within ten days after the publication, the application will be referred to a full Board hearing. ${ }^{118}$ Once approved and issued, drilling permits remain in full force and effect for a period of six months from the date of issuance. ${ }^{119}$

Once a well has been drilled, the Board will not enter a permanent spacing order until such time as the productive capability of a well has been confirmed by, at a minimum, perforation and testing within the formation for which permanent spacing is sought. More often than not, the permanent spacing unit will mirror the temporary spacing unit for the well. The spacing statute gives the Board authority to deal with the different drainage patterns of vertical and increasingly popular horizontal wells in fields where the drilling and completion techniques of both types are present. This allows the Board to harmonize the different drainage patterns in a fashion that will protect correlative rights. ${ }^{120}$ Again, there is no requirement that wells drilled on statewide

The Board has had no compunction in authorizing special temporary units that are comprised of adjacent and adjoining governmental quarter-quarter sections located in up to four governmental sections that, taken together, approximate a quarter section in size and configuration.

There are no statutory or regulatory mandates for permanent spacing following successful well completion. A temporary spacing unit must remain in effect until superseded by an order issued by the Board or until a permanent spacing unit is established. See Mont. Code Ann. $\S$ 82-11-201(2) (1997).

Mont. Code Ann. $§ 82-11-201(6)$ (1997).

Mont. Code Ann. $\$ 82-10-504$ (1997).

A protest to the granting of a permit to drill a wildcat well must be in writing, setting forth the protestant's name, address, and telephone number, the ownership interest in the affected lands, and the grounds for the protest. It must be received by the Board no later than ten days after the date of latest publication. See Mont. Admin. R. 36.22.601(6) (1997). Mont. Admin. R. 36.22.604(3) (1997).

120 Mont. Code Ann. $\$ 82-11-201(3)$ provides, in pertinent part:

Permanent spacing units do not need to be uniform in size or shape but must result in the efficient and economic development of the pool as a whole. In establishing permanent spacing units, the acreage to be embraced within a unit and the shape of the unit must be determined by the board based upon evidence introduced at the hearing. The board may divide a pool into zones and establish spacing units for each zone if necessary for a purpose mentioned in subsection (1) [waste prevention, avoid the drilling of unnecessary wells, and protection of correlative rights] or to facilitate production through the use of innovative drilling and completion methods. The spacing units within the zone may differ in size and shape from spacing units in any other zone but may not be smaller than the area that can be 
cost-bearing owner, being "liable for further costs as if the refusing owner had originally agreed to drilling of the well." 129

The risk-refusal penalties provided by the Montana forced pooling statute are of great interest to operators. Essentially, if an owner has refused to join in the costs of a proposed operation, the following amounts are included as costs to be recovered by the agreeing owners in addition to the actual costs of the operation:

(1) 100 percent of the refusing owner's share of the cost of newly acquired surface equipment beyond the wellhead connections including, but not limited to, stock tanks, separators, treaters, pumping equipment, and piping, plus 100 percent of the refusing owner's share of the cost of operation of the well commencing with first production and continuing until the agreeing owners have recovered the costs; and

(2) 200 percent of the refusing owner's share of the costs and expenses of staking, well site preparation, obtaining rights-of-way, rigging up, drilling, reworking, deepening or plugging back, testing, and completing the well, after deducting any cash contributions received from the refusing owners by the agreeing owners, and 200 percent of that portion of the cost of equipment in the well, including the wellhead connections. ${ }^{130}$

The non-joinder penalties have been made applicable to temporary spacing units in the case of wildcat wells. ${ }^{131}$ Thus, following successful completion of a wildcat well, the operator or other agreeing owners may seek permanent spacing and, upon receiving an order for the same, request a forced pooling order awarding costs, including the risk-penalty items noted above, to be recovered out of the refusing owner's share of production from the permanent spacing unit. ${ }^{132}$

Montana's statutory regime also provides for compulsory unitization in the absence of a voluntary agreement for "enhanced recovery purposes" ${ }^{133}$ for oil and gas units and for the increase of ultimate recovery or to prevent waste in gas units. Compulsory unitization is initiated "at least" sixty days prior "to application" by a certified or

Mont. Code Ann. $\$ 82-11-202(2)$ (c) (1997).

Mont. Code Ann. $\$ 82-11-202$ (2)(b) (1997). The wording of the statute leaves no discretion to be exercised by the Board in the imposition of the non-joinder penaltics.

Mont. Code Ann. § 82-11-203(2)(e) (1997).

As a practical matter, separate applications for permanent spacing and forced pooling are usually filed contemporaneously with the Board first hearing the application for permanent spacing and then, assuming the application is granted as submitted, hearing the application for forced pooling and making its determination and order with respect thereto.

"'Enhanced recovery' means the increased recovery from a pool achieved by artificial means or by the application of energy extrinsic to the pool; such artificial means or application includes pressuring, cycling, pressure maintenance, or injection into the pool of any substance or form of energy as is contemplated in secondary recovery or tertiary programs but does not include the injection in a well of a substance or form of energy for the sole purpose of aiding in the lifting of fluids in the well or stimulating of the reservoir at or near the well by mechanical, chemical, thermal, or explosive means." See Mont. Code Ann. § 82-11-101(6) (1997). 
implementing or enforcing the order. ${ }^{142}$ The petitioner has the option of filing the action in either the district court of the county in which the lands affected by the order are located, or in Lewis and Clark County District Court (Helena, in Lewis and Clark County, is where the Board presently maintains its principal office). The suit will be given a preferential trial setting and will be heard de novo as an ordinary civil suit and not upon the record of any hearing before the Board. ${ }^{143}$ During the pendency of the appeal, the Board order in question will be treated as prima facie valid. However, any finding of fact the Board may have made in support of its order is not binding on the court even though evidence in support of the order was introduced at the Board hearing of the matter. Moreover, the likelihood of obtaining a temporary injunction or restraining order pending the appeal is quite remote. ${ }^{144}$ As a practical matter, historically there have been few appeals from orders of the Montana Board of Oil and Gas Conservation. ${ }^{145}$

An ancillary matter which must be addressed is conservation regulation of public domain and Indian lands. The issue of whether federal and Indian lands are subject to state conservation regulation has been a long-standing topic of dispute spawning a plethora of litigation involving the interplay between state spacing and pooling regulations and the effect, if any, of those regulations on public domain and Indian lands. ${ }^{146}$ The northern Rocky Mountain states, in differing degrees, all claim jurisdiction to regulate oil and gas operations on federal and Indian lands.

Montana claims regulatory jurisdiction over lands of the United States or lands subject to federal jurisdiction, but

142 Mont. Code Ann. \$ 82-11-144 (1997).

143 Ibid.

14 Mont. Code Ann. $\$ 82-11-145$ (1997).

iss Following trial of the appeal, the Court shall:

(1) compel Board action unlawfully withheld or unreasonably delayed;

(2) hold unlawful and set aside Board action, findings and conclusions found to be:

(a) arbitrary, unreasonable, capricious, and abuse of discretion or otherwise not in accordance with law;

(b) contrary to constitutional right, power, privilege, or immunity;

(c) in excess of statutory jurisdiction, authority, or limitations or short of statutory right;

(d) without observance of procedure required by law; or

(e) unwarranted by the facts; and

(3) consider all the evidence, pass on the credibility of witnesses and the weight to be given their testimony, and resolve such fact issues as may be necessary for decision in the case.

See Mont. Code Ann. \$82-11-144 (1997).

For extensive treatment of these issues, see Ebner, "State and Local Regulation of Activities on Federal Oil and Gas Leases," Law of Federal Oil and Gas Leases $\$ 24.01$ et seq. (1986); Gray \& Schaefer, "Conflict Between Pooling Agreements and State Spacing and Pooling Orders" (1982) 27B Rocky Mtn. Min. L. Inst. 1517; Hubbard, "The Application of State Conservation Laws to Oil and Gas Operations on the Public Domain" (1960) 32 Rocky Mtn. Min. L. Rev. 109 (1960); Wilson, "State Spacing and Jurisdiction Over Conservation," Federal Onshore Oil and Gas Pooling and Unitization II 2-1 (Albany: Rocky Mtn. Min. L. Fdn., 1990). 
comity. ${ }^{153}$ Indeed, federal courts have consistently determined that various provisions of the Mineral Leasing Act effectively prohibit state conservation regulation from applying to federal lands or lessees absent consent from the Secretary of the Interior or other authorized federal official. ${ }^{154}$

Fortunately, the BLM is specifically authorized to enter into cooperative agreements with states, other federal agencies, and Indian tribes concerning oil and gas development and operations. ${ }^{155}$ These cooperative agreements, or memoranda of understanding, offer a device whereby state conservation commission and BLM conservation efforts may be coordinated to provide a more consistent approach to conservation issues involving federal and Indian tracts and neighbouring fee lands. Such agreements also foster the exchange of information, and in so doing, enhance the pool of technical expertise available to consider spacing, pooling, and other conservation matters. ${ }^{156}$

See, e.g.: 43 C.F.R. $§ 3162.3-1(a)$ :

Each well shall be drilled in conformity with an acceptable well-spacing program at a surveyed well location approved or prescribed by the authorized officer after appropriate environmental and technical reviews. An acceptable well-spacing program may be either (1) one which conforms with a spacing order or field rule issued by a state commission or board and accepted by the authorized officer, or (2) one which is located on a lease committed to a communitized or unitized tract at a location approved by the authorized officer, or (3) any other program established by the authorized officer.

43 C.F.R. \$ 3181.4(a):

Where state-owned land is to be unitized with federal lands, approval of the agreement by appropriate state officials must be obtained prior to its submission to the proper BLM office for final approval. When authorized by the laws of the state in which the unitized land is situated, appropriate provision may be made in the agreement, recognizing such laws to the extent that they are applicable to non-federal unitized land. (b) When Indian lands are included, modification of the unit agreement will be required where appropriate. Approval of an agreement containing Indian lands by the Bureau of Indian Affairs must be obtained prior to final approval by the authorized officer.

See e.g. Kirkpatrick Oil \& Gas v. United States, 675 F.2d 1122, 73 O.\&G.R. 351 (10th Cir. 1982); Texas Oil \& Gas v. Phillips Petroleum, 406 F.2d 1303, 32 O.\&G.R. 477 (10th Cir. 1969), affg, 277 F.Supp. 366, 28 O.\&G.R. 640 (W.D. Okla. 1967), cert. denied, 396 U.S. 829 (1969). See also Union Oil Co. of California, 77 IBLA 32 (1983), GFS(O\&G) 17 (1984); Bruce Anderson, 80 IBLA 286, 91 ID 203, GFS(O\&G) 121 (1984). Several commentators espouse the concept of "concurrent jurisdiction" as between the federal government and state regulatory agencies and commissions. Although a discussion of such state/federal jurisdictional relationships is well outside the scope of this article, readers wishing to gain an understanding of the policy struggles involved in administering the public domain are directed to the following publications: $R$. Cowart \& $S$. Fairfax, "Public Lands Federalism: Judicial Theory and Administrative Reality" (1989) 26 The Public Land \& Res. L. Dig. 222 [Originally appeared at (1988) 15 Ecology L.Q. 375]; Engdahl, "Conflicting Jurisdictions of Federal, State and Local Authorities: The Federal Preemption Doctrine" (1985) 31 Rocky Mtn. Min. L. Inst. 1-1; Engdahl, "State and Federal Power Over Federal Property" (1976) Federalism \& Energy Symposium 18 Ariz. L. Rev. 283; Berger \& Mounce, "Applicability of State Conservation and Other Laws To Indian and Public Lands" (1971) 16 Rocky Mtn. Min. L. Inst. 347; Williams, "Relationship Between State and Federal Government With Respect to Oil and Gas Matters" (1968) 19 Inst. On Oil \& Gas L. \& Tax'n 239; Hubbard, "The Application of State Conservation Laws to Oil and Gas Operations on the Public Domain" (1960) 32 Rocky Mtn. Min. L. Rev. 109.

43 C.F.R. $\$ 3161.2$ (1993).

See generally L. Moore \& M. Webster, "Indian Leasing" in Law of Federal Oil and Gas Leases $\S 26.10$ (Rocky Mountain Mineral Foundation, 1983). 
If the project involves federal lands in Montana or North Dakota, applicable rules and regulations may be obtained from the BLM state land office located in Billings, Montana. ${ }^{161}$ The BLM state land office in Cheyenne, Wyoming, should be contacted if operations are planned on federal lands in that state. ${ }^{162}$ Operations on Indian lands located in the northern Rocky Mountain states should be preceded by contact with either the BIA Area Office in Billings, Montana (for lands located in Montana or Wyoming), ${ }^{163}$ or the Aberdeen Area Office of the BIA (for lands located in North Dakota). ${ }^{164}$

\section{IMMIGRATION MATTERS}

Recent years have seen a dramatic influx of Canadian oil and gas industry professionals, such as geologists and petroleum engineers, into the northern Rocky Mountain states in connection with exploration and production activities. It is very important that all foreign persons in the United States have a valid immigration status, either as a non-immigrant or an immigrant ("green card" holder). United States federal law requires employers to verify the employment eligibility of all employees, which is accomplished on "Form I-9."165 This requirement, of course, includes Canadians who enter the United States under applicable provisions of the North American Free Trade Agreement. ${ }^{166}$ A foreign citizen who enters the United States improperly, for example, as a visitor for pleasure though intending to work, or who fails to maintain immigration status, runs a serious risk which, depending upon the circumstances, could result in difficulties, such as being barred from the United States.

Commonly used work visas include "Category E" (treaty trader/investor), "Category H1B" (specialty occupation - a classification currently capped at 115,000 visas annually), and "Category L" (intracompany transferee), all of which are non-immigrant categories. ${ }^{167}$ Canadian citizens also enjoy immigration benefits under NAFTA which are primarily focused on the temporary entry of certain "professionals." ${ }^{168}$ A qualified immigration law practitioner can also advise whether a claim to United States citizenship may be made - this is sometimes an available option if an individual has American ancestors. In short, cost and inconvenience will be minimized by reviewing the procedural and substantive complexities of immigration matters prior to having personnel attempt entry into the United States for purposes of participating in oil and gas operations in the northern Rocky Mountain states.

The address for the Burcau of Land Management, Montana State Office, is 222 North 32nd Street, P.O. Box 36800, Billings, Montana 59107-6800. Telephone No. (406) 255-2904.

The address for the Bureau of Land Management, Wyoming State Office, is 2515 Warren Avenue, P.O. Box 1828, Cheyenne, Wyoming 82003. Telephone No. (307) 775-6001.

The address for the Bureau of Indian Affairs, Billings Area Office, is 316 North 26th Street, Billings, Montana 59101. Telephone No. (406) 247-7943.

The address for the Bureau of Indian Affairs, Aberdeen Area Office, is 115 - 4th Avenue, S.E., Aberdeen, South Dakota 37401. Telephone No. (605) 226-7343.

See $\$ 274 \mathrm{~A}$ of the Immigration and Nationality Acl, 8 U.S.C. $\$ 1324 \mathrm{a}$ (1998).

8 C.F.R. $\$ 214.6$ (1999) [hercinafter NAFTA].

8 C.F.R. $\$ 214.2$ (1998).

Among other qualifications to benefit, the individual must qualify for one of the professions set forth in Appendix 1603.D.1 of NAFTA, ibid. 